\title{
Sensitivity and specificity of the macimorelin test for diagnosis of AGHD
}

\author{
Jose M Garcia ${ }^{1}$, Beverly M K Biller ${ }^{2}$, Márta Korbonits ${ }^{3}$, Vera Popovic ${ }^{4}$, Anton Luger ${ }^{5}$, Christian J Strasburger ${ }^{6}$, \\ Philippe Chanson ${ }^{7}$, Ronald Swerdloff ${ }^{8}$, Christina Wang ${ }^{8}$, Rosa Rosanna Fleming ${ }^{9}$, Fredric Cohen ${ }^{9}$, Nicola Ammer ${ }^{10}$, \\ Gilbert Mueller ${ }^{10}$, Nicky Kelepouris ${ }^{11}$, Frank Strob| ${ }^{11}$, Vlady Ostrow ${ }^{11}$ and Kevin C J Yuen ${ }^{12}$
}

${ }^{1}$ GRECC VA Puget Sound HCS/University of Washington, Seattle, Washington, USA

${ }^{2}$ Massachusetts General Hospital, Neuroendocrine Unit, Boston, Massachusetts, USA

${ }^{3}$ Barts and the London School of Medicine, Queen Mary University of London, Endocrinology, London, UK

${ }^{4}$ University of Belgrade, Medical Faculty, Belgrade, Serbia

${ }^{5}$ Division of Endocrinology and Metabolism, Medical University, General Hospital, Vienna, Austria

${ }^{6}$ Charité-Universitätsmedizin, Clinical Endocrinology CCM, Berlin, Germany

${ }^{7}$ Assistance Publique-Hôpitaux de Paris, Hôpital de Bicêtre, Service d'Endocrinologie et des Maladies de la Reproduction, Centre de Référence des Maladies Rares de l'Hypophyse, and Université Paris-Saclay, Univ. Paris-Sud, Inserm, Signalisation Hormonale, Physiopathologie Endocrinienne et Métabolique, Le Kremlin-Bicêtre, France

${ }^{8}$ The Lundquist Institute at Harbor-UCLA Medical Center, Torrance, California, USA

${ }^{9}$ Strongbridge Biopharma, Trevose, Pennsylvania, USA

${ }^{10}$ Aeterna Zentaris GmbH, Frankfurt, Hessen, Germany

${ }^{11}$ Novo Nordisk Inc., Plainsboro, New Jersey, USA

${ }^{12}$ University of Arizona College of Medicine and Creighton School of Medicine, Barrow Pituitary Center, Barrow Neurological Institute, Phoenix, Arizona, USA

Correspondence should be addressed to N Kelepouris: nlkp@novonordisk.com

\begin{abstract}
Objective: The macimorelin test is approved for the diagnosis of adult growth hormone deficiency (AGHD) based on its efficacy vs the insulin tolerance test (ITT). Macimorelin has a significant advantage over ITT in avoiding hypoglycemia. Analyses were conducted to determine whether macimorelin performance is affected by age, BMI, or sex, and evaluate its performance vs ITT over a range of GH cutpoints.

Design: Post hoc analyses of data from a previous randomized phase 3 study included participants aged 18-66 years with $\mathrm{BMI}<37 \mathrm{~kg} / \mathrm{m}^{2}$ and high (Group A), intermediate (Group B), or low (Group C) likelihood for AGHD based on pituitary history, and matched controls (Group D).

Methods: Probability of AGHD was estimated using unadjusted, age-adjusted, BMIadjusted, and sex-adjusted logistic models. Area under the curve (AUC) of the estimated receiver operating characteristic (ROC) curve (range, $0-1 ; 1=$ perfect) was compared for adjusted vs unadjusted models. Separate analyses evaluated agreement, sensitivity, and specificity for macimorelin and ITT using cutpoints of $2.8,4.0,5.1$, and $6.5 \mathrm{ng} / \mathrm{mL}$. Results: For participants in Group A ( $n=41)$ and Group D $(n=29)$, unadjusted, ageadjusted, BMI-adjusted, and sex-adjusted models had ROC AUCs (95\% Cls) of 0.9924 (0.9807-1), 0.9924 (0.9807-1), 0.9916 (0.9786-1), and 0.9950 (0.9861-1), respectively. Conclusions: Macimorelin performance was not meaningfully affected by age, BMI, or sex, indicating robustness for AGHD diagnosis. Of the $4 \mathrm{GH}$ cutpoints evaluated, the cutpoint of $5.1 \mathrm{ng} / \mathrm{mL}$ provided maximal specificity (96\%) and high sensitivity (92\%) and was in good overall agreement with the ITT at the same cutpoint (87\%).
\end{abstract}

\author{
Key Words \\ - macimorelin \\ - adult growth hormone \\ deficiency \\ - diagnosis \\ - insulin tolerance test
}

Endocrine Connections (2021) 10, 76-83 


\section{Introduction}

Adult growth hormone deficiency (AGHD) is a clinical syndrome characterized by abnormal body composition, unfavorable cardiovascular risk, cardiac dysfunction, decreased bone mineral density, and glucose intolerance $(1,2)$. Findings from recent studies suggest that hypopituitarism is associated with excess mortality $(3,4,5$, $6,7)$, in part due to $\operatorname{AGHD}(8,9)$. In addition, if untreated, AGHD can increase the risk of future bone fractures, obesity, diabetes, dyslipidemia, and cardiovascular and cerebrovascular disease $(10,11,12)$. Quality of life can also be negatively affected in patients with untreated AGHD as a result of fatigue, depression, anxiety, sleep impairment, sexual dysfunction, weight gain, reduced cognition, lack of energy, and/or social isolation $(12,13)$.

Treatment of AGHD with growth hormone (GH) replacement therapy has been shown to improve many, but not all, of the clinical features of AGHD (14). However, the diagnosis of AGHD is challenging because the clinical presentation of this syndrome is often nonspecific, with many features resembling those of metabolic syndrome $(15,16)$. Furthermore, when AGHD is suspected, there are no reliable biomarkers to guide clinicians on diagnosis and disease progression (17). Thus, except in patients with panhypopituitarism and low insulin-like growth factor I (IGF-I) levels, the diagnosis of AGHD often requires confirmation using a provocative GH stimulation test (GHST) $(18,19,20)$. The current gold standard GHST advocated by several consensus guidelines is the insulin tolerance test (ITT) $(18,19,20$, 21). However, the widespread use of the ITT is limited by several factors (22), including the requirement for close medical supervision by a physician throughout the test. The ITT may also be unpleasant for some patients and is associated with increased risks for severe hypoglycemia and hypoglycemia-related seizures, as well as exacerbation of the cardiovascular and cerebrovascular disease. Notably, patients with high BMI often require higher doses of insulin $(\geq 2 \mathrm{IU} / \mathrm{kg})$ to achieve an adequate hypoglycemic response, which in turn predisposes these patients to delayed hypoglycemia after test completion. As a result of these safety concerns, the ITT is contraindicated in elderly patients and in those with underlying seizure disorders or cardiovascular disease $(11,23,24,25)$. If AGHD is suspected and the ITT is contraindicated or not feasible, the glucagon stimulation test can be used as an alternative GHST. However, the diagnostic accuracy of the glucagon stimulation test is unclear, and the test is time-consuming (3-4 h), requires intramuscular injection, and is associated with bothersome side effects, including nausea, vomiting, and headache (19).

Macimorelin is an orally active ghrelin receptor agonist that is indicated for the diagnosis of AGHD in the United States (26) and Europe (27). Macimorelin is well-tolerated; the most frequent side effect is transient and mild dysgeusia (28). The macimorelin GHST has a more favorable safety profile, is more convenient, only requires four blood draws for serum GH measurements, and takes less time to conduct than the ITT and the glucagon stimulation test $(28,29,30,31)$. In a recent phase 3 study, the diagnostic performance of macimorelin was comparable to that of the ITT when using an a priori cutpoint value of $2.8 \mathrm{ng} / \mathrm{mL}$ for macimorelin and $5.1 \mathrm{ng} / \mathrm{mL}$ for the ITT (28).

Previous studies have reported that in order to improve the reliability of the GH-releasing hormone plus arginine (GHRH-arginine) $(32,33,34)$ and glucagon stimulation tests $(30,35,36,37)$, BMI-dependent GH cutpoints should be used. Herein we report results of post hoc analyses of data from the phase 3 study (28) of macimorelin, evaluating its performance by age, BMI, sex, and different GH cutpoint values.

\section{Materials and methods}

These post hoc analyses were performed using data from the previously published phase 3, open-label, randomized, multicenter, 2-way crossover study that validated the efficacy and safety of macimorelin by comparing this test with the ITT for the diagnosis of AGHD (28). The study protocol was approved by institutional review boards at each of the included study sites in the United States and Europe. The study was conducted in compliance with the Declaration of Helsinki and its amendments and the International Conference on Harmonisation Guideline for Good Clinical Practice (28).

\section{Study participants and procedures}

Detailed methods of the study have been reported previously (28). Briefly, analyses were performed using data from 140 participants aged 18-66 years with BMI $<37 \mathrm{~kg} / \mathrm{m}^{2}$ and varying degrees of likelihood for AGHD. Participants were classified as having high (Group A), intermediate (Group B), or low (Group C) likelihood for AGHD and were compared with matched healthy 
controls (Group D). Participants were considered to have a high likelihood of AGHD (Group A) if they had a structural hypothalamic or pituitary lesion and low serum IGF-I levels plus $\geq 3$ other pituitary hormone deficiencies, or childhood-onset GHD with structural lesions and low serum IGF-I levels. Participants were considered to have a low likelihood of AGHD (Group C) if they had 1 risk factor for AGHD (e.g. history of distant traumatic brain injury, only 1 other pituitary hormone deficiency, or childhoodonset isolated GHD). Participants were considered to have an intermediate likelihood of AGHD (Group B) if they did not meet the criteria for Groups A or C. Matching participants in Group A with participants in Group D was based on age, sex, BMI, and estrogen status (28).

Participants were randomized to undergo either the macimorelin GHST (Aeterna Zentaris, Frankfurt, Germany) followed by the ITT or the ITT followed by the macimorelin GHST. The ITT was performed with regular human insulin obtained from pharmacy stock. Serum GH concentrations were measured using an ultrasensitive validated immunochemiluminescence assay (IDS-iSYS human GH) (38) that is standardized to the World Health Organization recombinant $\mathrm{GH}$ calibration standard (98/574) and complies with recommendations for assay standardization (39). GHSTs were performed 7-28 days apart under fasted conditions. Test results were considered 'positive' for GHD if the peak GH value was less than a cutpoint established a priori; tests were considered 'negative' for GHD if the peak GH value was greater than or equal to this cutpoint (28). In the primary analysis (28), the GH cutpoints determined a priori were $2.8 \mathrm{ng} / \mathrm{mL}$ for the macimorelin test and $5.1 \mathrm{ng} / \mathrm{mL}$ for the ITT.

\section{Analysis of the effects of age, BMI, and sex on macimorelin performance}

This analysis included participants in the high likelihood of AGHD group (Group A) and the matched controls (Group D). Study participants in Group A were assumed to be 'true AGHD-positive' subjects, and those in Group D were assumed to be 'true AGHD-negative' subjects (28).

The probability of AGHD was estimated using four logistic models, with peak GH level as the explanatory variable, fitted to the data: unadjusted, age-adjusted, BMI-adjusted, and sex-adjusted. Each model considered all subjects as independent observations, not accounting for matching.

The area under the curve (AUC) of the estimated receiver operating characteristic (ROC) curve (range of $0-1$, where 1 is perfect) was measured after administration of the macimorelin GHST. ROC AUC results from each adjusted model were compared with results from the unadjusted model. Estimated sensitivity and specificity were calculated for each model using macimorelin cutpoint values of 2.8 and $5.1 \mathrm{ng} / \mathrm{mL}$. Estimated sensitivity and specificity from the model adjusted for BMI were calculated at the minimum, mean, median, and maximum BMI values of study participants.

\section{Analysis of macimorelin vs ITT performance over a range of $\mathrm{GH}$ cutpoints}

The percentage agreement (negative, positive, and overall) between tests was determined using GH cutpoint values of $2.8,4.0,5.1$, and $6.5 \mathrm{ng} / \mathrm{mL}$ for both the macimorelin GHST and the ITT in participants from all study groups (A, $\mathrm{B}, \mathrm{C}$, and D). The cutpoint of $2.8 \mathrm{ng} / \mathrm{mL}$ was selected based on a previous post hoc analysis (40). The cutpoint of 5.1 $\mathrm{ng} / \mathrm{mL}$ was evaluated because it is a validated and widely referenced cutpoint for the ITT $(23,41)$. The cutpoint of $4.0 \mathrm{ng} / \mathrm{mL}$ was selected because it is the approximate midpoint between 2.8 and $5.1 \mathrm{ng} / \mathrm{mL}$. The cutpoint of $6.5 \mathrm{ng} / \mathrm{mL}$ was evaluated because it is the lowest cutpoint that corresponded to an estimated sensitivity of $100 \%$ for the ITT. The percentage agreement between tests was calculated as the percentage of participants with the same finding (positive, negative, or overall (i.e. both positive and negative)) using a specified macimorelin cutpoint and a specified ITT cutpoint. Two-sided 95\% CIs of the percentage agreement between tests were calculated based on the Clopper-Pearson method (42).

The estimated specificity and sensitivity of both tests were determined at all cutpoints. Specificity was calculated as the percentage of participants in Group D (healthy controls) with a negative finding using the specified $\mathrm{GH}$ cutpoint. Sensitivity was calculated as the percentage of participants in Group A (high likelihood of AGHD) with a positive finding using the specified GH cutpoint.

\section{Results}

Effects of age, BMI, and sex on macimorelin performance

Overall, the analysis included 41 participants with a high likelihood of AGHD (Group A) and 29 healthy controls (Group D). Demographic characteristics were comparable between participants in Group A and Group D. Overall, the mean (SD) age was 41.7 (13.9) years, and the ages of

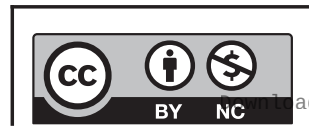

This work is licensed under a Creative Commons Attribution-NonCommercial 4.0 International License. ded from Bioscientifica.com at 04/26/2023 09:23:03AM 
all participants ranged from 18 to 66 years. The mean (SD) BMI was $27.1(4.0) \mathrm{kg} / \mathrm{m}^{2}$ (range, $20.4-36.6 \mathrm{~kg} / \mathrm{m}^{2}$ ). Thirty-nine of $70(55.7 \%)$ participants were male. As expected, mean (SD); range peak GH concentration was substantially lower in Group A (0.91 (1.9); 0.1-8.6 ng/mL) than in Group D (16.2 (7.4); 2.2-34.6 ng/mL).

Performance of the macimorelin test was not meaningfully affected by age, BMI, or sex (Fig. 1). The ROC AUC $(95 \%$ CI) for the unadjusted model was 0.9924 (0.9807-1) compared with $0.9924(0.9807-1)$ for the ageadjusted model $(P=1), 0.9916(0.9786-1)$ for the BMIadjusted model $(P=0.6861)$, and $0.9950(0.9861-1)$ for the sex-adjusted model $(P=0.4207)$.

Using the macimorelin cutpoint of $2.8 \mathrm{ng} / \mathrm{mL}$, estimated sensitivity was $88 \%$ and specificity was $97 \%$ for the unadjusted model (Table 1). These values remained the same when adjusting for age and for mean or median BMI. Adjusting for maximum BMI $\left(36.6 \mathrm{~kg} / \mathrm{m}^{2}\right)$ resulted in sensitivity of $76 \%$ and specificity of $100 \%$. When adjusting for sex, sensitivity was $88 \%$ for both males and females; specificity was $100 \%$ for males and $93 \%$ for females (Table 1).

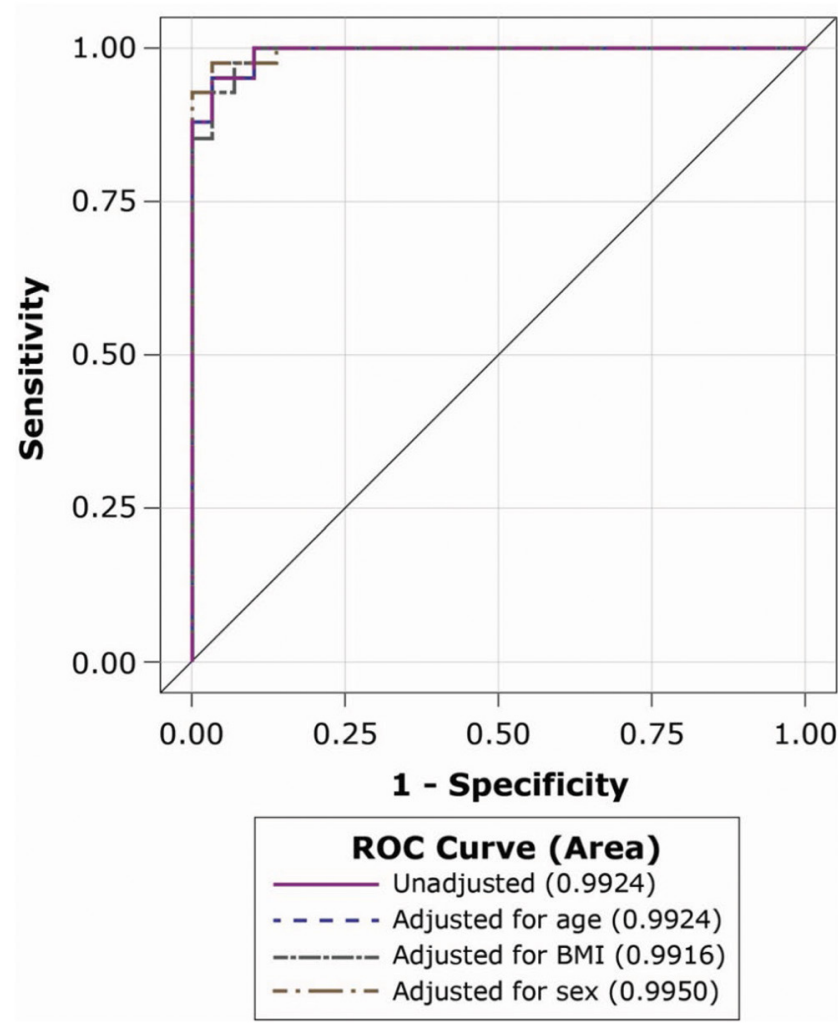

Figure 1

Macimorelin test ROC curves for the unadjusted model and models adjusted for age, BMI, and sex. ROC, receiver operating characteristic.
Table 1 Estimated sensitivity and specificity at the prespecified macimorelin cutpoint of $2.8 \mathrm{ng} / \mathrm{mL}$ in unadjusted and adjusted models.

\begin{tabular}{|c|c|c|c|}
\hline & $\begin{array}{c}\text { Sensitivity, } \\
\%(95 \% \mathrm{Cl})\end{array}$ & $\begin{array}{l}\text { Specificity, } \\
\%(95 \% \mathrm{Cl})\end{array}$ & Covariate value \\
\hline Unadjusted & $88(74-96)$ & $97(82-100)$ & - \\
\hline Adjusted for age & $88(74-96)$ & $97(82-100)$ & - \\
\hline Adjusted for BMI & $90(77-97)$ & $97(82-100)$ & Minimum $\mathrm{BMI}=20.4 \mathrm{~kg} / \mathrm{m}^{2}$ \\
\hline Adjusted for BMI & $88(74-96)$ & $97(82-100)$ & Mean $\mathrm{BMI}=27.1 \mathrm{~kg} / \mathrm{m}^{2}$ \\
\hline Adjusted for BMI & $88(74-96)$ & $97(82-100)$ & Median $\mathrm{BMI}=26.7 \mathrm{~kg} / \mathrm{m}^{2}$ \\
\hline Adjusted for BMI & $76(60-88)$ & $100(88-100)$ & Maximum $\mathrm{BMI}=36.6 \mathrm{~kg} / \mathrm{m}^{2}$ \\
\hline Adjusted for sex & 88 (64-99) & $93(66-100)$ & Female sex \\
\hline Adjusted for sex & $88(68-97)$ & $100(78-100)$ & Male sex \\
\hline
\end{tabular}

Using the macimorelin cutpoint of $5.1 \mathrm{ng} / \mathrm{mL}$, sensitivity was $93 \%$ and specificity was $97 \%$ for the unadjusted model. These values remained the same when adjusting for age and mean BMI. When adjusting for sex, sensitivity was $92 \%$ for males and $94 \%$ for females, and specificity was $100 \%$ for males and $93 \%$ for females (Table 2).

\section{Macimorelin vs ITT performance over a range of GH cutpoints}

This analysis included participants in the modified intentto-treat population $(n=140$; all randomized participants with evaluable data from both the macimorelin GHST and the ITT). Participants included those with a high (Group A; $n=38$ ), intermediate (Group B; $n=37$ ), or low (Group C; $n=40$ ) likelihood for AGHD and healthy matched controls (Group D; $n=25$ ). Using an ITT cutpoint of 5.1 $\mathrm{ng} / \mathrm{mL}, 74$ participants were classified as GH-deficient and 66 were classified as GH-sufficient.

Selecting the same cutpoint values for macimorelin and the ITT yielded high positive (Table 3), negative (Table 4), and overall (Table 5) agreement rates. At a GH cutpoint value of $2.8 \mathrm{ng} / \mathrm{mL}$ for both tests, positive agreement was $87.1 \%$ (95\% CI, 76.2-94.3\%), negative agreement was 93.6\% (95\% CI, 85.7-97.9\%), and overall agreement was 90.7\% (95\% CI, 84.6-95.0\%). At a GH cutpoint value of $5.1 \mathrm{ng} / \mathrm{mL}$ for both

Table 2 Estimated sensitivity and specificity at the macimorelin cutpoint of $5.1 \mathrm{ng} / \mathrm{mL}$ in unadjusted and adjusted models.

\begin{tabular}{|c|c|c|c|}
\hline & $\begin{array}{c}\text { Sensitivity, } \\
\%(95 \% \mathrm{Cl})\end{array}$ & $\begin{array}{l}\text { Specificity, } \\
\%(95 \% \text { Cl) }\end{array}$ & Covariate value \\
\hline Unadjusted & 93 (80-99) & $97(82-100)$ & - \\
\hline Adjusted for age & $93(80-99)$ & $97(82-100)$ & - \\
\hline Adjusted for BMI & 95 (84-99) & 93 (77-99) & Minimum $\mathrm{BMI}=20.4 \mathrm{~kg} / \mathrm{m}^{2}$ \\
\hline Adjusted for BMI & $93(80-99)$ & $97(82-100)$ & Mean $\mathrm{BMI}=27.1 \mathrm{~kg} / \mathrm{m}^{2}$ \\
\hline Adjusted for BMI & $93(80-99)$ & 93 (77-99) & Median $\mathrm{BMI}=26.7 \mathrm{~kg} / \mathrm{m}^{2}$ \\
\hline Adjusted for BMI & 90 (77-97) & $97(82-100)$ & Maximum BMI $=36.6 \mathrm{~kg} / \mathrm{m}^{2}$ \\
\hline Adjusted for sex & $94(71-100)$ & $93(66-100)$ & Female sex \\
\hline Adjusted for sex & $92(73-99)$ & $100(78-100)$ & Male sex \\
\hline
\end{tabular}


Table 3 Percentage $(95 \% \mathrm{CI})$ positive agreement between the macimorelin GHST and the ITT at different cutpoints among participants with a positive finding for each ITT cutpoint.

\begin{tabular}{|c|c|c|c|c|}
\hline \multirow[b]{2}{*}{ Macimorelin cutpoint, $\mathrm{ng} / \mathrm{mL}$} & \multicolumn{4}{|c|}{ ITT cutpoint, ng/mL } \\
\hline & $2.8(n=62 / 140)$ & $4.0(n=67 / 140)$ & $5.1(n=74 / 140)$ & $6.5(n=82 / 140)$ \\
\hline 2.8 & $87.1 \%(76.2-94.3 \%)$ & $80.6 \%(69.1-89.2 \%)$ & $74.3 \%(62.8-83.8 \%)$ & $68.3 \%(57.1-78.1 \%)$ \\
\hline 4.0 & $88.7 \%(78.1-95.3 \%)$ & $82.1 \%(70.8-90.4 \%)$ & $78.4 \%(67.3-87.1 \%)$ & $72.0 \%(60.9-81.3 \%)$ \\
\hline 5.1 & $90.3 \%(80.1-96.4 \%)$ & $86.6 \%(76.0-93.7 \%)$ & $82.4 \%$ (71.8-90.3\%) & $75.6 \%(64.9-84.4 \%)$ \\
\hline 6.5 & $93.6 \%(84.3-98.2 \%)$ & 89.6\% (79.7-95.7\%) & $87.8 \%(78.2-94.3 \%)$ & $81.7 \%$ (71.6-89.4\%) \\
\hline
\end{tabular}

Results in italics are based on using the same cutpoints for macimorelin and the ITT. $n=$ number of participants with a positive finding using the specified ITT cutpoint.

GHST, growth hormone stimulation test; ITT, insulin tolerance test.

tests, positive agreement was 82.4\% (95\% CI, 71.8-90.3\%), negative agreement was 92.4\% (95\% CI, 83.2-97.5\%), and overall agreement was $87.1 \%$ (95\% CI, 80.4-92.2\%).

Assuming that all participants in Group A $(n=38)$ were AGHD cases and that all participants in Group D $(n=25)$ were healthy controls, the macimorelin GHST and the ITT had identical estimated specificities of $96 \%$ at $\mathrm{GH}$ cutpoint values of $2.8,4.0$, or $5.1 \mathrm{ng} / \mathrm{mL}$. At the GH cutpoint of $5.1 \mathrm{ng} / \mathrm{mL}$, the estimated sensitivity was 92\% with the macimorelin GHST and 97\% with the ITT. Increasing the $\mathrm{GH}$ cutpoint to $6.5 \mathrm{ng} / \mathrm{mL}$ increased the sensitivity of the macimorelin test to $97 \%$ and the ITT to $100 \%$. However, these increases in sensitivity were at the expense of decreased specificity (92 and 88\%, respectively, for the macimorelin test and the ITT at $6.5 \mathrm{ng} / \mathrm{mL}$ ). Sensitivity and specificity values varied slightly when calculated using the regression models (data not shown).

\section{Discussion}

The results of these post hoc analyses confirm the robust performance of the macimorelin GHST for the diagnosis of AGHD by sex, within the ranges of age (18-66 years) and BMI (20.4-36.6 kg/m²) evaluated, and across a range of $\mathrm{GH}$ cutpoints. At the $4 \mathrm{GH}$ cutpoints evaluated, the macimorelin test maintained its sensitivity and specificity, with high levels of agreement with the ITT.
In contrast to the GHRH-arginine test $(32,33,34)$ and glucagon stimulation test $(30,35,36,37,43)$, for which BMI-dependent GH cutpoints have been recommended to improve their reliability (19), the findings from this study indicate that the performance of the macimorelin test is neither affected by BMI $\left(\leq 36.6 \mathrm{~kg} / \mathrm{m}^{2}\right)$ nor sex using the cutpoints of 2.8 and $5.1 \mathrm{ng} / \mathrm{mL}$. This is particularly noteworthy given that endogenous $\mathrm{GH}$ secretion is known to be affected by body weight and estrogen levels $(25,44,45)$. For example, recent data indicate that for the oral glucose tolerance test, BMI, sex, and use of oral contraceptives containing estradiol can significantly affect GH nadir levels, suggesting that the GH cutpoints used to diagnose acromegaly with this test may need to be adjusted based on patient characteristics $(46,47)$. Importantly, there is also a strong negative correlation between BMI and $\mathrm{GH}$ response when using the ITT, and some researchers have proposed the need to use substantially higher GH cutpoints for individuals without vs individuals with obesity $(25,44)$.

Peak GH levels after administration of ghrelin are significantly reduced in older men and women compared with younger individuals (48). Nevertheless, our results suggest that, in the age range studied (18-66 years) and with the GH cutpoints selected in our study population, age does not significantly affect the performance of the test.

However, several limitations of these analyses must be acknowledged. These results may not be generalizable to

Table 4 Percentage $(95 \% \mathrm{Cl})$ negative agreement between the macimorelin GHST and the ITT at different cutpoints among participants with a negative finding for each ITT cutpoint.

\begin{tabular}{l}
$\begin{array}{l}\text { Macimorelin cutpoint, } \\
\mathbf{n g} / \mathbf{m L}\end{array}$ \\
\hline 2.8 \\
4.0 \\
5.1 \\
6.5
\end{tabular}

\begin{tabular}{|c|c|c|c|}
\hline \multicolumn{4}{|c|}{ ITT cutpoint, ng/mL } \\
\hline $2.8(n=78 / 140)$ & $4.0(n=73 / 140)$ & $5.1(n=66 / 140)$ & $6.5(n=58 / 140)$ \\
\hline $93.6 \%$ (85.7-97.9\%) & $93.2 \%$ (84.7-97.7\%) & $93.9 \%(85.2-98.3 \%)$ & $94.8 \%(85.6-98.9 \%)$ \\
\hline $91.0 \%$ (82.4-96.3\%) & $90.4 \%$ (81.2-96.1\%) & $93.9 \%$ (85.2-98.3\%) & $94.8 \%$ (85.6-98.9\%) \\
\hline $87.2 \%$ (77.7-93.7\%) & $89.0 \%$ (79.5-95.2\%) & $92.4 \%(83.2-97.5 \%)$ & $93.1 \%(83.3-98.1 \%)$ \\
\hline $80.8 \%$ (70.3-88.8\%) & $82.2 \%(71.5-90.2 \%)$ & $87.9 \%(77.5-94.6 \%)$ & $89.7 \%$ (78.8-96.1\%) \\
\hline
\end{tabular}

Results in italics are based on using the same cutpoints for macimorelin and the ITT. $n=$ number of participants with a negative finding using the specified ITT cutpoint.

GHST, growth hormone stimulation test; ITT, insulin tolerance test.

$\begin{array}{lr}\text { https://ec.bioscientifica.com } & \text { (c) } 2021 \text { The authors } \\ \text { https://doi.org/10.1530/EC-20-0491 } & \text { Published by Bioscientifica Ltd }\end{array}$

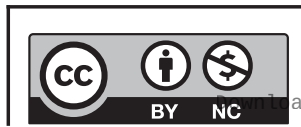


Table 5 Percentage $(95 \% \mathrm{CI})$ overall agreement between the macimorelin GHST and the ITT at different cutpoints.

\begin{tabular}{|c|c|c|c|c|}
\hline \multirow[b]{2}{*}{ Macimorelin cutpoint, ng/mL } & \multicolumn{4}{|c|}{ ITT cutpoint, ng/mL } \\
\hline & $2.8(n=140)$ & $4.0(n=140)$ & $5.1(n=140)$ & $6.5(n=140)$ \\
\hline 2.8 & $90.7 \%(84.6-95.0 \%)$ & $87.1 \%(80.4-92.2 \%)$ & $83.6 \%(76.4-89.3 \%)$ & $79.3 \%(71.6-85.7 \%)$ \\
\hline 4.0 & $90.0 \%(83.8-94.4 \%)$ & $86.4 \%$ (79.6-91.6\%) & $85.7 \%(78.8-91.1 \%)$ & $81.4 \%(74.0-87.5 \%)$ \\
\hline 5.1 & $88.6 \%(82.1-93.3 \%)$ & $87.9 \%(81.3-92.8 \%)$ & $87.1 \%(80.4-92.2 \%)$ & $82.9 \%(75.6-88.7 \%)$ \\
\hline 6.5 & $86.4 \%$ (79.6-91.6\%) & $85.7 \%(78.8-91.1 \%)$ & $87.9 \%(81.3-92.8 \%)$ & $85.0 \%(78.0-90.5 \%)$ \\
\hline
\end{tabular}

Results in italics are based on using the same cutpoints for macimorelin and the ITT. $n=$ number of participants with findings for both the macimorelin GHST and the ITT.

GHST, growth hormone stimulation test; ITT, insulin tolerance test.

elderly or pediatric patients or to individuals with severe obesity. The study inclusion criteria restricted participants to the age range of 18-66 years (28). The highest recorded baseline BMI was $36.6 \mathrm{~kg} / \mathrm{m}^{2}$, and most participants had a BMI of $<30 \mathrm{~kg} / \mathrm{m}^{2}$. Furthermore, analysis by sex did not include consideration for menopausal status among female participants. Additionally, this study involved a relatively small sample size and excluded patients with poorly controlled diabetes.

In conclusion, these post hoc analyses of macimorelin for the diagnosis of AGHD in patients with a high likelihood of AGHD vs matched controls indicate that the test performance is robust and is not meaningfully affected by age, baseline BMI $\left(\leq 36.6 \mathrm{~kg} / \mathrm{m}^{2}\right)$, or sex over a range of GH cutpoints. In addition, when evaluating the entire study population, using the same cutpoint of $2.8 \mathrm{ng} / \mathrm{mL}$ for both the macimorelin test and the ITT resulted in high levels of positive (87.1\%), negative (93.6\%), and overall (90.7\%) agreement between tests, which were higher than agreement levels using a cutpoint of $5.1 \mathrm{ng} / \mathrm{mL}$ for both tests. Finally, sensitivity of the macimorelin test was greatest at a cutpoint of $6.5 \mathrm{ng} / \mathrm{mL}$ but was at the expense of a decline in specificity from 96 to $92 \%$, which may be undesirable if the primary consideration is the minimization of false-positive diagnosis of AGHD. Of the $4 \mathrm{GH}$ cutpoints evaluated, the cutpoint of $5.1 \mathrm{ng} / \mathrm{mL}$ provided maximal specificity (96\%) and high sensitivity $(92 \%)$ and was in good overall agreement with the ITT at the same cutpoint (87\%).

\section{Declaration of interest}

J M G has served as an advisor and/or investigator for Aeterna Zentaris, Pfizer, and Novo Nordisk. B M K B has served as a consultant and/or an investigator for OPKO Biologics, Novo Nordisk, Strongbridge Biopharma, Aeterna Zentaris, Ascendis, Merck Serono, and Pfizer. M K has served as an advisor, an investigator, and/or a speaker for Pfizer, Ono, Ipsen, Novo Nordisk and Novartis. V P has served as an advisor, an investigator, and/or a speaker for Novo Nordisk, Pfizer, and Novartis. A L has served as an advisor, an investigator, and/or a speaker for Aeterna Zentaris, Ipsen, Merck Serono, Novo Nordisk, Pfizer, and Sandoz. C J S has served as a consultant for Aeterna Zentaris, Ascendis, Chiasma, Ipsen, Merck Serono,
Novartis, Novo Nordisk, Pfizer, Sandoz, and Strongbridge Biopharma. $P C$ has served as an advisor, an investigator, and/or a speaker for Aeterna Zentaris, Ipsen, Novartis, Novo Nordisk, Pfizer, Italpharmaco, Antisense, Prolor Biotech, Sandoz, and Eli Lilly. R S has been an investigator for Clarus, Antares, and Novartis. C W has received research support from Clarus Therapeutics, Antares, and TesoRx. R R F and F C are employees of Strongbridge Biopharma. N A is an employee of Aeterna Zentaris $\mathrm{GmbH}$. G M was an employee of Aeterna Zentaris $\mathrm{GmbH}$ at the time of study conduct and study data analysis. N K, F S, and $\mathrm{V} O$ are employees of Novo Nordisk Inc. K C J Y has served as an advisor, an investigator, and/or a speaker for Pfizer, Novo Nordisk, Strongbridge, Ascendis, Ipsen, and Novartis.

\section{Funding}

This work was sponsored by Aeterna Zentaris. The commercial rights to macimorelin in the United States and Canada have been licensed from Aeterna Zentaris to Novo Nordisk.

\section{Acknowledgements}

The authors acknowledge the nurses, study coordinators, subinvestigators, and patients involved in the study, as well as medical writing assistance from Cherie Koch, PhD, and Amy Ross, PhD (PRECISIONscientia, Yardley, PA).

\section{References}

1 Møller N \& Jørgensen JO. Effects of growth hormone on glucose, lipid, and protein metabolism in human subjects. Endocrine Reviews 200930 152-177. (https://doi.org/10.1210/er.2008-0027)

2 Ramos-Leví AM \& Marazuela M. Treatment of adult growth hormone deficiency with human recombinant growth hormone: an update on current evidence and critical review of advantages and pitfalls. Endocrine 201860 203-218. (https://doi.org/10.1007/s12020-0171492-1)

3 Burman P, Mattsson AF, Johannsson G, Höybye C, Holmer H, Dahlqvist P, Berinder K, Engström BE, Ekman B, Erfurth EM, et al. Deaths among adult patients with hypopituitarism: hypocortisolism during acute stress, and de novo malignant brain tumors contribute to an increased mortality. Journal of Clinical Endocrinology and Metabolism 201398 1466-1475. (https://doi.org/10.1210/jc.20124059)

4 Hammarstrand C, Ragnarsson O, Hallén T, Andersson E, Skoglund T, Nilsson AG, Johannsson G \& Olsson DS. Higher glucocorticoid replacement doses are associated with increased mortality in patients with pituitary adenoma. European Journal of Endocrinology 2017177 251-256. (https://doi.org/10.1530/EJE-170340)

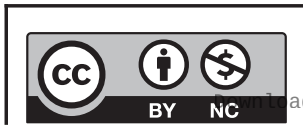

This work is licensed under a Creative Commons Attribution-NonCommercial 4.0 International License. ded from Bioscientifica.com at 04/26/2023 09:23:03AM 
5 Jasim S, Alahdab F, Ahmed AT, Tamhane S, Prokop LJ, Nippoldt TB \& Murad MH. Mortality in adults with hypopituitarism: a systematic review and meta-analysis. Endocrine 201756 33-42. (https://doi. org/10.1007/s12020-016-1159-3)

6 Olsson DS, Nilsson AG, Bryngelsson IL, Trimpou P, Johannsson G $\&$ Andersson E. Excess mortality in women and young adults with nonfunctioning pituitary adenoma: a Swedish nationwide study. Journal of Clinical Endocrinology and Metabolism 2015100 2651-2658. (https://doi.org/10.1210/jc.2015-1475)

7 Pappachan JM, Raskauskiene D, Kutty VR \& Clayton RN. Excess mortality associated with hypopituitarism in adults: a meta-analysis of observational studies. Journal of Clinical Endocrinology and Metabolism 2015100 1405-1411. (https://doi.org/10.1210/jc.20143787)

8 Bülow B, Hagmar L, Mikoczy Z, Nordström CH \& Erfurth EM. Increased cerebrovascular mortality in patients with hypopituitarism. Clinical Endocrinology 199746 75-81. (https://doi. org/10.1046/j.1365-2265.1997.d01-1749.x)

9 Tomlinson JW, Holden N, Hills RK, Wheatley K, Clayton RN, Bates AS, Sheppard MC \& Stewart PM. Association between premature mortality and hypopituitarism. West Midlands Prospective Hypopituitary Study Group. Lancet 2001357 425-431. (https://doi. org/10.1016/s0140-6736(00)04006-x)

10 Giovannini L, Tirabassi G, Muscogiuri G, Di Somma C, Colao A \& Balercia G. Impact of adult growth hormone deficiency on metabolic profile and cardiovascular risk. (Review). Endocrine Journal 201562 1037-1048. (https://doi.org/10.1507/endocri.EJ15-0337)

11 Reed ML, Merriam GR \& Kargi AY. Adult growth hormone deficiency - benefits, side effects, and risks of growth hormone replacement. Frontiers in Endocrinology 20134 64. doi:10.3389/ fendo.2013.00064

12 Kargi AY \& Merriam GR. Diagnosis and treatment of growth hormone deficiency in adults. Nature Reviews: Endocrinology 20139 335-345. (https://doi.org/10.1038/nrendo.2013.77)

13 Brod M, Pohlman B, Højbjerre L, Adalsteinsson JE \& Rasmussen MH Impact of adult growth hormone deficiency on daily functioning and well-being. BMC Research Notes 20147 813. (https://doi. org/10.1186/1756-0500-7-813)

14 Yuen KCJ, Llahana S \& Miller BS. Adult growth hormone deficiency: clinical advances and approaches to improve adherence. Expert Review of Endocrinology and Metabolism 201914 419-436. (https://doi. org/10.1080/17446651.2019.1689119)

15 Johannsson G \& Bengtsson BA. Growth hormone and the metabolic syndrome. Journal of Endocrinological Investigation 199922 (Supplement) 41-46.

16 Attanasio AF, Mo D, Erfurth EM, Tan M, Ho KY, Kleinberg D, Zimmermann AG, Chanson P \& International Hypopituitary Control Complications Study Advisory Board. Prevalence of metabolic syndrome in adult hypopituitary growth hormone (GH)-deficient patients before and after GH replacement. Journal of Clinical Endocrinology and Metabolism 201095 74-81. (https://doi. org/10.1210/jc.2009-1326)

17 Yuen KC, Tritos NA, Samson SL, Hoffman AR \& Katznelson L. American Association of Clinical Endocrinologists and American College of Endocrinology Disease State Clinical Review: update on growth hormone stimulation testing and proposed revised cut-point for the glucagon stimulation test in the diagnosis of adult growth hormone deficiency. Endocrine Practice 201622 1235-1244. (https:// doi.org/10.4158/EP161407.DSCR)

18 Molitch ME, Clemmons DR, Malozowski S, Merriam GR, Vance ML $\&$ Endocrine Society. Evaluation and treatment of adult growth hormone deficiency: an Endocrine Society clinical practice guideline. Journal of Clinical Endocrinology and Metabolism 201196 1587-1609. (https://doi.org/10.1210/jc.2011-0179)

19 Yuen KCJ, Biller BMK, Radovick S, Carmichael JD, Jasim S, Pantalone KM \& Hoffman AR. American Association of Clinical
Endocrinologists and American College of Endocrinology guidelines for management of growth hormone deficiency in adults and patients transitioning from pediatric to adult care. Endocrine Practice 201925 1191-1232. (https://doi.org/10.4158/ GL-2019-0405)

20 Ho KK \& 2007 GH Deficiency Consensus Workshop Participants. Consensus guidelines for the diagnosis and treatment of adults with GH deficiency II: a statement of the GH Research Society in Association with the European Society for Pediatric Endocrinology, Lawson Wilkins Society, European Society of Endocrinology, Japan Endocrine Society, and Endocrine Society of Australia. European Journal of Endocrinology 2007157 695-700. (https://doi.org/10.1530/ EJE-07-0631)

21 Hoffman DM, O'Sullivan AJ, Baxter RC \& Ho KK. Diagnosis of growth-hormone deficiency in adults. Lancet 1994343 1064-1068. (https://doi.org/10.1016/s0140-6736(94)90181-3)

22 Gordon MB, Levy RA, Gut R \& Germak J. Trends in growth hormone stimulation testing and growth hormone dosing in adult growth hormone deficiency patients: results from the ANSWER Program. Endocrine Practice 201622 396-405. (https://doi.org/10.4158/ EP14603.OR)

23 Biller BM, Samuels MH, Zagar A, Cook DM, Arafah BM, Bonert V, Stavrou S, Kleinberg DL, Chipman JJ \& Hartman ML. Sensitivity and specificity of six tests for the diagnosis of adult GH deficiency. Journal of Clinical Endocrinology and Metabolism 200287 2067-2079. (https:// doi.org/10.1210/jcem.87.5.8509)

24 Agrawal V \& Garcia JM. The macimorelin-stimulated growth hormone test for adult growth hormone deficiency diagnosis. Expert Review of Molecular Diagnostics 201414 647-654. (https://doi.org/10. 1586/14737159.2014.915746)

25 Glynn N \& Agha A. Diagnosing growth hormone deficiency in adults. International Journal of Endocrinology 20122012972617. (https://doi.org/10.1155/2012/972617)

26 Macrilen (Prescribing Information). Trevose, PA: Strongbridge Biopharma Inc, 2018.

27 Macimorelin (Summary of Product Characteristics). Frankfurt am Main, Germany: Aeterna Zentaris GmBH, 2019.

28 Garcia JM, Biller BMK, Korbonits M, Popovic V, Luger A, Strasburger CJ, Chanson P, Medic-Stojanoska M, Schopohl J, Zakrzewska A, et al. Macimorelin as a diagnostic test for adult GH deficiency. Journal of Clinical Endocrinology and Metabolism 2018103 3083-3093. (https://doi.org/10.1210/jc.2018-00665)

29 Yuen KCJ. Growth hormone stimulation tests in assessing adult growth hormone deficiency. In Endotext [Internet]. Eds KR Feingold, B Anawalt, A Boyce, et al. South Dartmouth, MA: MDText.com Inc, 2000-2020.

30 Yuen KC, Biller BM, Katznelson L, Rhoads SA, Gurel MH, Chu O, Corazzini V, Spiller K, Gordon MB, Salvatori R, et al. Clinical characteristics, timing of peak responses and safety aspects of two dosing regimens of the glucagon stimulation test in evaluating growth hormone and cortisol secretion in adults. Pituitary 201316 220-230. (https://doi.org/10.1007/s11102-0120407-7)

31 Leong KS, Walker AB, Martin I, Wile D, Wilding J \& MacFarlane IA. An audit of 500 subcutaneous glucagon stimulation tests to assess growth hormone and ACTH secretion in patients with hypothalamic-pituitary disease. Clinical Endocrinology 200154 463-468. (https://doi.org/10.1046/j.1365-2265.2001.01169.x)

32 Makimura H, Stanley T, Mun D, You SM \& Grinspoon S. The effects of central adiposity on growth hormone $(\mathrm{GH})$ response to GH-releasing hormone-arginine stimulation testing in men. Journal of Clinical Endocrinology and Metabolism 200893 4254-4260. (https:// doi.org/10.1210/jc.2008-1333)

33 Colao A, Di Somma C, Savastano S, Rota F, Savanelli MC, Aimaretti G \& Lombardi G. A reappraisal of diagnosing GH deficiency in adults: role of gender, age, waist circumference, and body mass index.

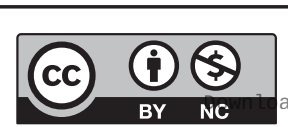

This work is licensed under a Creative Commons Attribution-NonCommercial 4.0 International License. ded from Bioscientifica.com at 04/26/2023 09:23:03AM 
Journal of Clinical Endocrinology and Metabolism 200994 4414-4422. (https://doi.org/10.1210/jc.2009-1134)

34 Bonert VS, Elashoff JD, Barnett P \& Melmed S. Body mass index determines evoked growth hormone $(\mathrm{GH})$ responsiveness in normal healthy male subjects: diagnostic caveat for adult GH deficiency. Journal of Clinical Endocrinology and Metabolism 200489 3397-3401. (https://doi.org/10.1210/jc.2003-032213)

35 Hamrahian AH, Yuen KC, Gordon MB, Pulaski-Liebert KJ, Bena J $\&$ Biller BM. Revised GH and cortisol cut-points for the glucagon stimulation test in the evaluation of GH and hypothalamic-pituitaryadrenal axes in adults: results from a prospective randomized multicenter study. Pituitary 201619 332-341. (https://doi. org/10.1007/s11102-016-0712-7)

36 Wilson JR, Utz AL \& Devin JK. Effects of gender, body weight, and blood glucose dynamics on the growth hormone response to the glucagon stimulation test in patients with pituitary disease. Growth Hormone and IGF Research 201626 24-31. (https://doi.org/10.1016/j. ghir.2015.12.005)

37 Dichtel LE, Yuen KC, Bredella MA, Gerweck AV, Russell BM, Riccio AD, Gurel MH, Sluss PM, Biller BM \& Miller KK. Overweight/ obese adults with pituitary disorders require lower peak growth hormone cutoff values on glucagon stimulation testing to avoid overdiagnosis of growth hormone deficiency. Journal of Clinical Endocrinology and Metabolism 201499 4712-4719. (https://doi. org/10.1210/jc.2014-2830)

38 Manolopoulou J, Alami Y, Petersenn S, Schopohl J, Wu Z, Strasburger CJ \& Bidlingmaier M. Automated $22-\mathrm{kD}$ growth hormone-specific assay without interference from pegvisomant. Clinical Chemistry 201258 1446-1456. (https://doi.org/10.1373/clinchem.2012.188128)

39 Clemmons DR. Consensus statement on the standardization and evaluation of growth hormone and insulin-like growth factor assays. Clinical Chemistry 201157 555-559. (https://doi.org/10.1373/ clinchem.2010.150631)

40 Garcia JM, Swerdloff R, Wang C, Kyle M, Kipnes M, Biller BM, Cook D, Yuen KC, Bonert V, Dobs A, et al. Macimorelin (AEZS-130)stimulated growth hormone $(\mathrm{GH})$ test: validation of a novel oral stimulation test for the diagnosis of adult GH deficiency. Journal of Clinical Endocrinology and Metabolism 201398 2422-2429. (https:// doi.org/10.1210/jc.2013-1157)

41 Chanson P, Cailleux-Bounacer A, Kuhn JM, Weryha G, Chabre O, Borson-Chazot F, Dubois S, Vincent-Dejean C, Brue T, Fedou C, et al.
Comparative validation of the growth hormone-releasing hormone and arginine test for the diagnosis of adult growth hormone deficiency using a growth hormone assay conforming to recent international recommendations. Journal of Clinical Endocrinology and Metabolism 201095 3684-3692. (https://doi.org/10.1210/jc.20100295)

42 Tobi H, van den Berg PB \& de Jong-van den Berg LT. Small proportions: what to report for confidence intervals? Pharmacoepidemiology and Drug Safety 200514 239-247. (https://doi. org/10.1002/pds.1081)

43 Diri H, Karaca Z, Simsek Y, Tanriverdi F, Unluhizarci K, Selcuklu A \& Kelestimur F. Can a glucagon stimulation test characterized by lower GH cut-off value be used for the diagnosis of growth hormone deficiency in adults? Pituitary 201518 884-892. (https://doi. org/10.1007/s11102-015-0666-1)

$44 \mathrm{Qu}$ XD, Gaw Gonzalo IT, Al Sayed MY, Cohan P, Christenson PD, Swerdloff RS, Kelly DF \& Wang C. Influence of body mass index and gender on growth hormone $(\mathrm{GH})$ responses to $\mathrm{GH}$-releasing hormone plus arginine and insulin tolerance tests. Journal of Clinical Endocrinology and Metabolism 200590 1563-1569. (https://doi. org/10.1210/jc.2004-1450)

45 Deutschbein T, Bidlingmaier M, Schopohl J, Strasburger CJ \& Petersenn S. Anthropometric factors have significant influence on the outcome of the GHRH-arginine test: establishment of normative data for an automated immunoassay specifically measuring $22 \mathrm{kDa}$ human growth hormone. European Journal of Endocrinology 2017176 273-281. (https://doi.org/10.1530/EJE-16-0668)

46 Schilbach K, Gar C, Lechner A, Nicolay SS, Schwerdt L, Haenelt M, Dal J, Jørgensen JL, Störmann S, Schopohl J, et al. Determinants of the growth hormone nadir during oral glucose tolerance test in adults. European Journal of Endocrinology 2019181 55-67. (https://doi. org/10.1530/EJE-19-0139)

47 Monaghan PJ \& Trainer PJ. Determinants of the growth hormone nadir during oral glucose tolerance test in adults. European Journal of Endocrinology 2019181 C17-C20. (https://doi.org/10.1530/EJE-190661)

48 Broglio F, Benso A, Castiglioni C, Gottero C, Prodam F, Destefanis S, Gauna C, van der Lely AJ, Deghenghi R, Bo M, et al. The endocrine response to ghrelin as a function of gender in humans in young and elderly subjects. Journal of Clinical Endocrinology and Metabolism 2003 88 1537-1542. (https://doi.org/10.1210/jc.2002-021504)

Received in final form 27 November 2020

Accepted 14 December 2020

Accepted Manuscript published online 15 December 2020 https://ec.bioscientifica.com https://doi.org/10.1530/EC-20-0491 (c) 2021 The authors Published by Bioscientifica Ltd
This work is licensed under a Creative Commons Attribution-NonCommercial 4.0 International License. ded from Bioscientifica.com at 04/26/2023 09:23:03AM 